\title{
A Tree Story: Narratives of Paraserianthes Falcataria L.Nielsen (Falcata) Farmers
}

\author{
Lorlaine Retes Dacanay ${ }^{1 *}$ \\ ${ }^{1}$ Cebu Normal University, Philippines \\ ${ }^{*}$ Corresponding author: Lorlaine R.Dacanay: ldacanat@gmail.com
}

\section{OPEN ACCESS}

Citation: Dacanay. L.R. (2018) A Tree Story: Narratives of Paraserianthes. Falcataria L.Nielsen (Falcata) Farmers. Open Science Journal 3(2)

Received: 20 ${ }^{\text {th }}$ December 2017

Accepted: $28^{\text {th }}$ May 2018

Published: $6^{\text {th }}$ July 2018

Copyright: (c) 2018 This is an open access article under the terms of the Creative Commons Attribution License, which permits unrestricted use, distribution, and reproduction in any medium, provided the original author and source are credited.

Funding: The author(s) received no specific funding for this work

Competing Interests: The author have declared that no competing interests exists.

\section{Abstract:}

The study narrates the plantation to industrialization processes of Falcata trees through the lens of the Falcata farmers. It recounts the: a) pre-planting story, b) planting story, c) harvest story, d) market story, and e) industry story. This is a narrative research, using post-structuralist approach, and putting forth three philosophical stances: logical positivism, narrative fidelity, and aesthetic finality. Pre-planting story progresses from the motivation of the farmers to plant and their challenges prior to planting season, soil and land preparation, and seedling choice. Planting Story is about the soil, financial matters, trees and the government support to the farming activities. Harvesting Story depends on the land area to be harvested, harvesting mode, harvesting activities and the owners' return of their investment. Market Story encompasses the search and selection of buyers; and the projected income if the trees are sold. Industrialization Story from the hind sight of the farmers whom only presume that these trees are made into particular products; but the method of making them is unknown to the farmers. The stories of assuring and distressful outlooks of tree farmers reveal much about the Falcata tree industry. Maintaining the stand point of narration, it is revealed that marketing comes before harvesting; and thus alters the order of narrative structure and content.

Keywords: Falcata trees, Farmer's Perspectives, Narrative Research, Tree Farming, Timber Species, Philippines, Asia 


\section{Introduction}

Tree farming in the Philippines has become an alternative income-generating agricultural activity among farmers. Timber trees have been grown to supply a growing demand in the local and international wood and paper industries. Researchers [1] state that among timber species, Paraserianthes falcataria or locally known as Falcata is not very common to be planted among tree growers (p. 1-2). With the recent knowledge [2] on the propagation of this type of tree species, farmers have begun to heed the call of forestry projects to generate income (p.2-3).

There are several studies $[2-3,6,9-10]$ regarding the Falcataria species from the Association of Southeast Asion Nation (ASEAN) countries like Vietnam, Thailand, Indonesia and the Philippines especially that these countries have suitable soil characteristics for Falcata farming (p.2, 64). Contents of these literatures are corroborated in the discussion as the farmers' stories unfold. Hence, my review is on the methodological dimension of this research.

For quantitative studies, the research designs are experimental such as the use of biotechnology, species trialling, intercropping, transplant [1, 4-6]; causal like stepwise form [7]; descriptive e.g. actual measurement [8]; purposive survey [9]; and evaluative studies such as anatomical assessment, feasibility evaluation and inventory [10-11]. For the qualitative designs, some authors use case studies of one country or one forest [11-12]; ethnography [13]; narrative studies with the aid of Landsat Satellite imagery [15]; and descriptive analytical reports [1, 16].

The studies obviously showed an array of designs to capture empirical data on forestry. However, what makes me interested in is about the farmers' lives and their constructed social realities. These farmers have grown different crops and trees before they began planting Falcata. Their reason of shifting plantation from common crops to Falcata is interesting.

The study narrates the plantation to industrialization process of Falcata trees through the lens of the Falcata farmers. It recounts the: a)pre-planting story, b) planting story, c) harvest story, d) market story, and e) industry story. The phases of the story are pre-emptive because the researcher uses the Aristotelian plot structure of narratives used in some literary studies to make the story linear and simple.

\section{Methodology}

Philosophical Underpinnings of the Design. Narrative research may use the Humanist Approach [17] or the Post-structuralist Approach (p. 3-5). While humanist narrative researchers focus on holistic, person-centered analysis, I use the Post-structuralist stance because my concern is on the structure and content finding fluidity and contradictions in narration. With this, I assume that stories are multiple, disunified subjectivities will be involved in the production and understanding of stories. The study is more explanatory than descriptive. Hence, I put forth three philosophical stances: logical positivism as I hope to maintain narrative probability; narrative fidelity as I desire that the farmers' true 
perception of their reality will be the bases for interpretation; and aesthetic finality as I capture their stories holistically in an artistic but practical form.

Ethnographic, case, and phenomenological studies could have been used as a method. Yet, capturing the embedded conflict of shifting from coconut, abaca, gemelina, corn, rice and root crop plantation to falcata farming is worthy of narrating. Morphological, topographic, biologic dimensions have been studied; and perceptive, communal and descriptive analyses of the farmers have been studied too. However, my study takes the parlance of a story gatherer to build a bigger story in the hope of sectioning the periodic development of being a Falcata farmer.

Narrative Plot Structure. This study still uses the same principles of narrative research; however, this makes use of the Aristotelian plot structure or also known as Freytag's pyramid. This was conceptualized by a German writer, Gustav Freytag in 1863. The pyramid starts with the beginning, rising action, climax, falling action and ending. In this case, the researcher also uses the same principle as shown in figure 1.

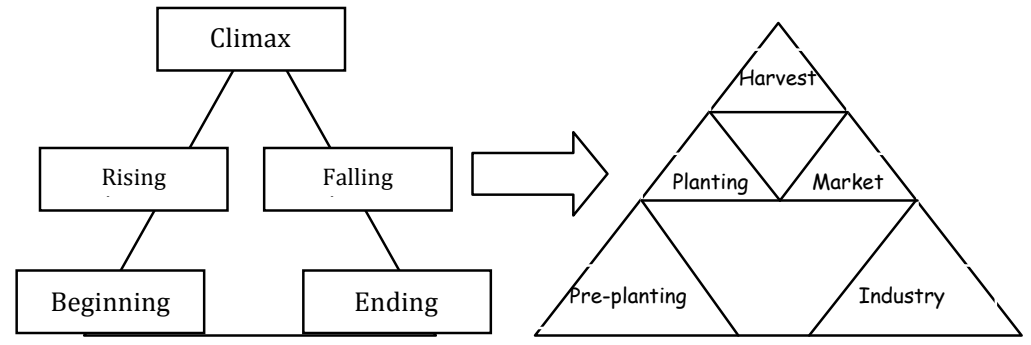

Figure 1: Aristotelian Plot Structure

Environment. The study explores the forestry activities in Sergio Osmena, Zamboanga del Norte (Lat. 8.167; Long. 123.500; Alt 700km). In region IX, this is a town which is less represented in the forest reports of the region. Narrating the embedded stories from the participants' responses gives another fresher angle of Falcata farmers.

Informants. Tree farmers can include all the social actors of tree farming: land owners, laborers, LGU-Department of Environment and Natural Resources personnel or Department of Agriculture personnel, harvester, marketer, and processor. The study considers all Falcata tree farmers in Sergio Osmeńa, Zamboanga del Norte to be eligible informants of the study. However, I used purposive sampling because the focal person, who is a 34-year-old tree farmer, knows prospective interviewees who would qualify the selection criteria. Firstly, they are included in the study if they sign the informed consent signifying their approval to be interviewed. Secondly, the informants should have tree farms which they tilled. Thirdly, they have breadth of knowledge with Falcata tree farming. The informants can be excluded if they do not have time to participate in the study and if they refuse to participate. Public notice is posted so the potential farmers would be the informants of the study. Due to the non-response of other farmers to the public notice, snowball sampling is used. The focal person and other farmers in the itnerview refer other farmers who would be interviewed.

The chosen informants were engaged in an in-depth interview and or natural conversation to reveal substantial data needed in the study. If the participant feels he is not knowledgeable of the present undertaking, he may feel free to withdraw from participation. All prospective participants are of legal age and are 
not vulnerable. There are no known risks associated to the study. Simple tokens are given as manifestation of gratitude for the participant's time and effort in participating in my study.

Instrument. The researcher as the main interpreter is the primary instrument of the study. Secondly, the study utilizes an interview guide. There are five sets of questions representing the five phases of the tree story. The five sets of developing questions are for pre-planting phase, planting phase, harvest phase, marketing phase and industrialization phase. The questions need to be translated by an independent translator; and it must undergo pilot testing to refine some questions. I asked my contact person to answer the questionnaire and I took note of the repetitive and unacceptable questions. Revision of the research instrument was done based on the expert's suggestion. The next step is to ask two forestry officials to validate the contents of the questions. Another revision is made.

Materials. Using Boolean operator coding, all annotated bibliographies from one through five sets mentioning Falcata are downloaded, read and analyzed. Studies are conducted using quantitative and qualitative approaches. These literatures have been reviewed in order to substantiate the discussion of this study.

Data-gathering Procedure. Data are gathered following these steps. First, I called a contact person to post public notices to let other farmers know about my research undertaking. While waiting for the responses, I asked two experts to validate my instrument. None of the farmers sent me a message; but there was one who promised my contact person that he would be willing to be interviewed. Second, the protocol was presented to seek approval from the research professor and sent the revised protocol to Cebu Normal University - Ethics Review Committee. Third, after receiving a notice to proceed, my contact person sent information sheet to be filled in by the participants who promised to participate, and gave the informed consent form so that he could read and decide whether he would pursue in participating. To get other participants, he recommended other farmers whom he knew. After reaching six participants, our search had stopped because all the stages of farming were represented. The same procedure had been done. Fourth, we need to revisit the participants to get the consent forms and the information sheets; and to agree on which time they would be available. Luckily, they preferred to be interviewed there and then. The interview was audiorecorded to document the process.

Data Analysis. Reflecting Freytag's pyramid, I will build up the micro-stories of farmers to make a bigger story subjected to time, order and change as shown in Table 1. 
Table 1: Matrix for Data Analysis

\begin{tabular}{|c|c|c|c|}
\hline Phases & Beginning & Middle & End \\
\hline Pre-Plantation & & & \\
\hline Plantation & & & \\
\hline Harvesting & & & \\
\hline Marketing & & & \\
\hline Industrialization & & & \\
\hline
\end{tabular}

Ethical Considerations. In narrative research, Andrews [17] has enumerated some of the guidelines and I take note of them in doing this study:

1. My ethical position is the recognition that ambivalence, non-universal and the irrational contradictions and tensions cannot be overcome but must be lived with.

2. Reflexivity is my awareness that the participants, their social spaces and my socio-cultural dimensions build the research knowledge.

3. Ownership and intellectual property rights are attributed to the participants for the stories but for the meaning making is attributed to the researcher. However, it must be known that without the participants, there can never be any knowledge made. Both need to be recognized.

4. Confidentiality is my awareness that the informants' need to be assured that data is for research-purposes. They can never be held liable for vulnerable stories told. Data files are deleted after the completion of the work.

5. Anonymity is my pledge to the informants that they should not be made known to the public. Aliases and code names are used.

6. Interpreted data must be reported back to the participants to check if there are irregularities in the story building.

7. There is no conflict of interest as I am not connected to any Forestry organizations; except that the investigation is conducted for school requirements and for scientific investigations for publication.

\section{Results}

The presentation of results follows the narrative structural elements of order, time and change. These are the miniature story guides for narration: preplanting, planting, harvesting, marketing, and industrialization.

PRE-PLANTING STORY as shown in Figure 2 progresses from the motivation of the farmers to plant and his challenges prior to planting season, soil and land preparation, and seedling choice. This is shown in figure 2. 


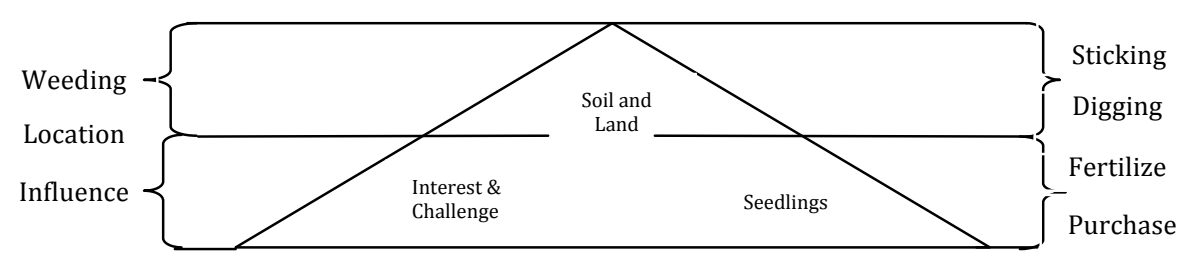

Figure 2: Pre-planting Key Concepts

The farmers' interest is rooted from their parents' influence. The fathers of the younger farmers have already started planting in the $1980 \mathrm{~s}$ that brought tangible income to the family; hence encouraging the adult sons to follow the steps of their fathers. In his statement, 'from my parents because they have already planted before [P1: 24-25] Anyway for them, the trees are far way too easy to manage. Having a high demand in the industry, Falcata farming is a resort to gain more income. In the statement of the participant, "For me, projected money motivated me because my father told me that even if it took time to take the trees for granted, time will come that they would be marketed. I will never plant if there is no income" [P2: 32-37]. Together with these hopes are the twinning challenges. Like in any business, the starting expenses might be too large for a starter farmer. Purchasing the seedlings and paying for labor are common expenditures. Added to it are the tiresome toils of the land. One participant recalled that "it needs more capital, it is tiresome too. It also needs more people to start with. I need the help of my father to figure out how to start" [P2: 51-54]. More people are needed to be hired to expedite the land preparation such as weeding, sticking and digging holes. At times, expert's advice come in handy in times of doubt. Getting an area to plant needs the experts' eyes to boost the first-time Falcata farmer's confidence that they are doing the right thing.

Farmers also have to ensure the land and soil to be planted. Land profile refers to the location and characteristics. The farmers can only wish that it is plain, not slope and steep; it is easy to visit and easy to harvest. However, with the number of years to wait, the farmers prefer to use the hilly, steep unused land rather than the plains because these plains are usable for other plants to grow such as the coconut. Viable soil for Falcata has the quality of being loam. Its color ranges from brown to dark or black, but never the red or clay soil. Quoted from a participant's response, "from our perspective, it is ought to have soft soil rather than the red and hard one. If the soil is hard, trees don't grow well. It is good to have the brown or dark soil" [P2:63-69]. A farmer even compared their average soil type to that of Lanao provinces as they have the best soil type good for growing and fruit bearing coconut. In preparing the land, cleaning the area, digging holes, fertilizing the soil need to pay people to work for the farmer. One participant admitted, "In my case, there are people who help because weeding, digging need people to work" [P1: 43-45]. Hired laborers can speed up the preparation stage. As long as the farmers have the capacity to pay the workers, tree farming is not too difficult for them.

Preparing the seedlings is also another dilemma. The sources of the seedlings can be bought from Zamboanga del Norte and Zamboanga del Sur. The farmer himself can spend for these seedlings or ask assistance from the government to supply them through the office of the Department of Agriculture. Other schemes also incorporate other actors such as the planters who signed an agreement with 
the farmers to plant in the farmer's lands. Part of that is they supply the needed seedlings. In their statements, "For me, the Department of Agriculture supplied me with seedlings" [P1:57]; "we bought taller seedlings from Zamboanga del Sur; the others are bought here in Zamboanga del Norte" [P2:58-60]). All these pose challenges, yet, the land owner and farmer has the final say. Transporting these seedlings from the nursery needs care. The taller seedlings are prone to be cut along the way especially that they are grown to be three (3) months old in bags. As they say, small and short trees are not good qualities to be planted; hence, they purchase taller seedlings. The road to the farms is never simple. Traversing the rocky, some slippery, steep and narrow roads, farmers need these seedlings to be safe and well-kept upon arrival in their farms.

PLANTING STORY as revealed in Figure 3 is about the benefits and challenges that farmers narrate in tree farming. They reveal their stories about the soil, financial matters, trees and the government support to the farming activities. These concepts are revealed below.

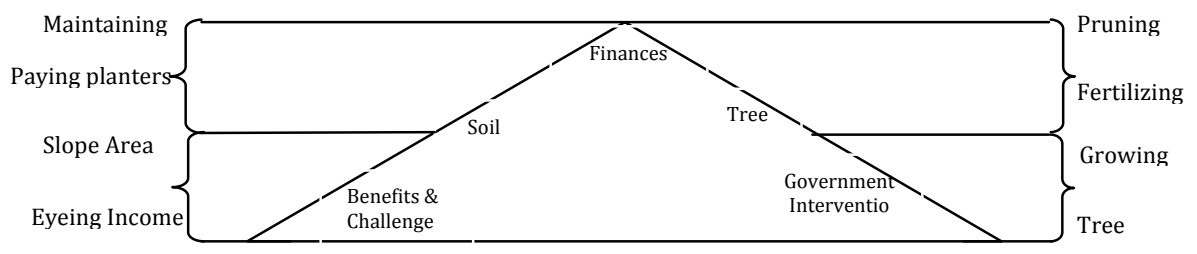

Figure 3: Planting Key Concepts

The farmers see the apparent benefits in tree farming. Planting falcata promises financial gains while the dry leaves of these trees also naturally fertilize the soil. These are without some difficulties too. The weather condition in the town is cool, characterized by constant moderate to heavy rainfall throughout the year. Wet roads make it slippery for farmers to walk through or ride through the paths. Accessibility of these roads is almost risky for the farmers because of mud. Aside from that, the land profile is steep and slope. These features worsen the situation of the farmers who plant trees. The farmers need to hire labourers to clean, stick, dig, and plant the trees. One farmer suggested, "First of all, the land must be ready for planting. It is even better if it has easy accessibility for easy harvest" [P2:94-95]. The farmer also has to be there to instruct the right distance among trees. Having planted the trees, it needs financial maintenance. The farmers cannot figure out the exact amount to spend in managing the farm; as they only hire laborers when there is available fund.

The other element farmers need to attend to is the soil. The soil profile is not being studied before planting. Soil has not been checked but farmers have chanceful growth of their trees. Most often, the land to be tilled are unused lands that sprawl for years without any produce. Upon planting, farmers know how to care for the soil. Weeding and fertilizing are common activities. The farmers suggest bigger space to plant. One hectare is the least land size to project profitability of one's effort. Because of the thought to have more tree count in a given space, others plant having $1 \mathrm{~m} \times 1 \mathrm{~m}$ measurements especially if the planters do not know about the growth characteristics of Falcata.

Other farmers use $3 \times 3$ measurements to harvest tall and straight trees. The new farmers now have planted using $4 \times 4$ measurements to give more space for the stem to grow its diameter; but these have to be monitored closely as the 
branches grow rapidly making the main stem crooked when it grows. It is not advisable to have $5 \times 5$ measurements too because it is a waste of space. Farmers can maximize the land area by planting abaca, coffee, and pepper in between spaces. In their statements, "In planting, we instruct the workers to plant trees with a distance of $4 \times 4$ [P1: 179-180]; that measurement is enough. It is even better to plant them $5 \times 5$ but we cannot plant more because the land size is limited [P2: 188-190]; we heard it is much better to have nearer measurement because the trees have straight growth [W: 329-331]; for wider measurement, trees take long to grow. For better marketing, it needs straight trees [H:334-336]".

Financial Maintenance in tree farming is almost climactic to farmers. They pay for seedlings which amount to P6 or P7 each, as P4 and P5 do not promise survival. "Just P5 or P6... there is even P4 but it is small. It is not good to plant tiny seedlings. Sometimes I buy short seedlings, I re-bag them from $4 \mathrm{x} 6$ to $6 \mathrm{x} 8$ [P5: 155-161]," the participants confessed. Paying for labor to plant and maintain the field also gets a big chunk in their capital. Paying P200 per person everyday for four to ten days is a burden for farmers who have no allocated budget. "For workers, we pay them P150 per person per day inclusive of meal [W: 294], P200 if there is no meal provided" [H: 296]), the farmers added.

Before the trees grow, planting them has more stories. Farmers need to learn the techniques by observing the planters in a corporation. They also ask assistance from their parents who have been in the business venture for years. For new farmers without access to this information, state-sponsored seminar is needed. A participant explained, "We just observed how they take care of the trees. I guess, they did not care for them well. We did not bother to add fertilizer because that was in our agreement" [W: 83-84]. The mode of planting depends on the land owner if he manages the planting by himself to get the share wholly for himself; by the planter to get $30 \%$ of the share; or by the corporation to get $50 \%$ of the share.

Growth maintenance is another challenge. They need to fertilize the soil using either manure or nitrogen. The trees are also closely monitored especially in pruning the branches. If the branches grow much bigger, it affects the main stem. Other farmers also graze cows to maintain the area clear from weeds. Cow's manure also fertilizes the soil. Growth rate of trees depends on the soil quality, planting site, planting distance and area or location. Climate affects the trees. "It also depends on the soil [P4: 68-69]; storms can distract the development of the roots. Trees get affected" [W: 344-347], they added. Cold weather ensures growth, but also allows worms to develop in the barks and stems of the trees. Hot weather may slow the growth, but helps the trees to avoid the development of parasites.

Farmers feel lucky if only $10 \%$ of their trees die; but during typhoons, it goes to $20 \%$. In a hectare of land with 600 planted trees, only 400 survived from the havoc caused by storms. Others also die if the farmers forget to weed the area. In their statements, "For 100 trees, there are 10 that die. We replant them [P1: 205206]; there are more damage during typhoons [H: 131\& W: 132]. Among more than a thousand trees planted, there are only 800 survived" [H: 133]. The vines outgrow the trees causing the trees to wither. Cold weather is allegedly pointed out by the farmers to have caused worms to develop inside the trees. With these pests within the barks, it is nil to get good harvest. 
Storms also cut the young soft-bodied falcata. Heavy wind causes the slow growth of these trees too. The development of the roots is spread across the ground. Its narrow foothold on the land makes the trees vulnerable to being uprooted. If not uprooted, it can bow the branches down, giving other twigs to develop from the arched main stem. This is already considered damaged as there is no good stem that can be expected from it. Time is the most precious element in tree planting. It takes years to wait before the farmers can get paid with their effort. They can only be happy if their trees grow healthily. They can have white or red falcata, ordinary or jumbo variety as long as the barks are smooth; they are already convinced that their plants are in good shape.

Government intervention is less except in their assistance to give seedlings freely. Department of Agriculture also has to monitor the registration of trees; but it is never strict if farmers ask permission before planting the trees. "In our farm, really? We have not asked yet from the DENR, I mean, we have not gotten them yet, but they promised to give us when the land is ready" [W: 96-98], replied the woman farmer. Other than that, it never provides fertilizer or machinery to the farmers. Hence, farmers have other sources of income while waiting for the harvest time. They plant abaca, coffee, pepper, banana in between spaces maximizing their land area. She added, "there is corn and vegetable garden. We also plant abaca in between the falcate because abaca grows best in hollow area" [W: 375-377].

HARVESTING STORY as exposed in Figure 4 is the shortest stage of tree farming. It depends on the land area to be harvested, harvesting mode, harvesting activities and the owner's return of his investment.

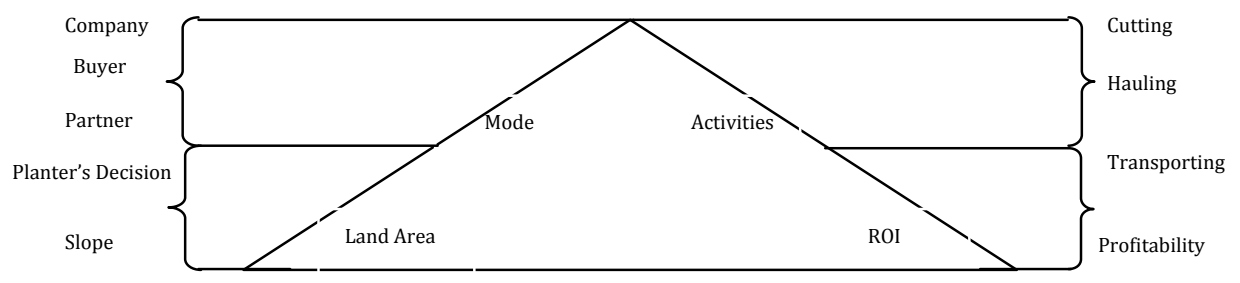

Figure 4: Harvesting Key Concepts

Land area to be harvested needs to be considered in harvesting. Firstly, the size of the land is the component to know how many workers are needed. The difficulty of the access to the farm is also considered; and the land form of the farm is also noted. Slope and steep farms make it difficult for the farmers to carry the trees uphill. A participant said, "Gosh, it seems I cannot estimate the exact expenses because it depends on our budget. If there are available funds, we work, but we cannot estimate the exact amount" [P4:47-51]. Other than that, trees to be harvested might also be a factor especially if it is mixed with other trees.

Proper machinery is needed to haul these trees. When the farmers are asked why they plant in these areas which are difficult to clamp trees during harvest, they responded that plains are good for coconut for them to watch over against thieves. If coconuts were planted on steep lands, it would be difficult to monitor the fruits. Falcata on the other hand is not prone to stealing; hence, no matter how difficult the area is for harvesting, it is the best location. In his words, "Most of the steep lands are not utilized; it is good for the trees to be planted on slope area because it is not good for the coconuts to grow there. There are a lot of 
people who steal coconuts; but who would steal trees. Cutting them notifies you directly" [P5: 76-80].

The mode to harvest depends on the land owner. If the owner pursues to harvest the trees, it is tiresome on his part. He hires people, machinery, trucks and gets permits from the government office to cut and transport trees. These may also mean transacting business with people in the office and on the hi-way. Another is through a harvester. These are paid personnel to put a price in a package harvest of trees depending on the land size. The other way is for the owner to contact the buyers. They buy the trees and harvest them, transport them to the industry, get the permits from the government office. A farmer told me, "We have buyer, they are the ones responsible for the cutting; they are also the ones to haul them" [P5: 45-46]. Lastly, the owners also own a company. He owns the land, he plants the trees; he hires his own harvester and sell them to the industry. The owner can really save if that is so. Farmers need not to complicate themselves. The most convenient way is to have other people to harvest the trees and the transaction ends when he gets paid.

Harvesting activities can be tiresome for a lone farmer. Cutting the trees need more permit from the government office and chain saws. The farmers never complain about this because they said, "It is already the buyer's responsibility. Usually here, aside from the farmers who plant, they also have people and machinery. They have less expense. But for me, that is tiresome. We need people and maintain truck, chain saw. I need the net income. When they were done harvesting last March, I planted again in May. Now, I already have man-tall trees" [P5: 110-121].

When the trees are from slope lands, hauling the trees downhill need trucks and loaders. It is also difficult because "most often, the area is slope. It is rare for falcate to be planted on plains" [P5: 71-72]. After tree collection, these have to be transported to the industry. The return of investment can only be felt after years of waiting for the trees to be finally harvested. It also depends on the use of the trees by which these are planted.

MARKET STORY as presented in Figure 5 is sometimes simultaneously done with harvesting phase. It can even come before harvest time. It encompasses the search and selection of buyers; and the projected income if the trees are sold.

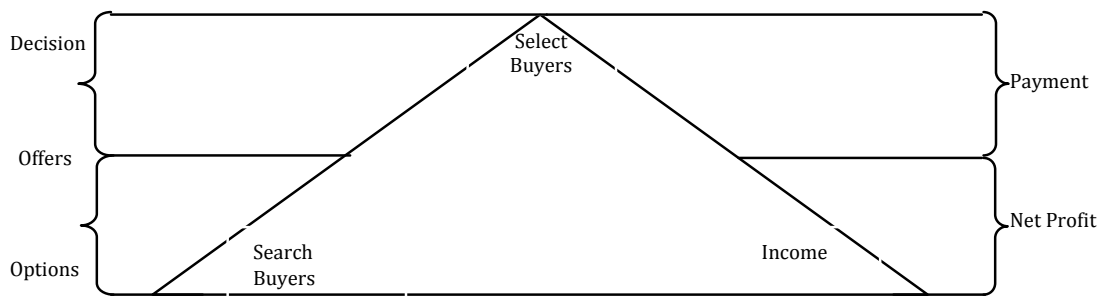

Figure 5: Marketing Key Concepts

The search for buyers is never difficult because the buyers themselves would come and transact with the farmers. Sometimes, the farmers wait for better offers among the buyers. They delay the marketing to wait for lucrative offers. Selecting buyers depend on the price the buyers pay. For them, "It depends on the contract if the company cuts the trees, or I cut the trees myself. It is all right for them to deliver or I deliver; they can also come and get the trees from the site" [P4: 84, 87-89]. 
There are legal buyers from the company, however, their offers might be too low because the paid staffs in the company. He continued, "There is a legal buyer but pays less. Scaling the trees could be a problem because they are in a company. Sometimes I need to bribe the scaler, if not I get paid less. That is a Filipino style" [P5: 175-180]). The owner can also sell the trees by himself. However, it is also prone to dishonest scaling of trees that owners only receive less than what is ought to be received. There are also merchandisers who slashed the price also. For instance, they only offer 1.8 million pesos for a hectare of land; while this same farm was sold to another buyer and three million pesos. So, it is up to the owner because for them, selling the trees is a return of their investment inclusive of a big profit; receiving more is a bonus.

The income farmers get from their farm after selling really depends on the size of the land area, the size of the trees, their age and their quality. Tree farming has minimal capital but the profit is too big. There are others who buy a hectare with 600 trees at 1.5 million pesos. But it also depends on the quality and size of the trees. There are others who even sell a single tree at P10, 000-P28, 000, but these trees are big and old. The wife and husband narrated that "J*****n has mentioned that in a hectare of land with 600 trees of good size like the bark of coconut, it sells 1.5 million [Natural Conversation, 78-79]; There is a buyer from Cagayan who bought a single tree at P10, 000. It is quite big. It can't even be hugged. There is one in Ariosa, it was bought at P23, 000" [Natural Conversation, 101-104].

INDUSTRIALIZATION STORY as shown in Figure 6 is also the longest phase but is already from the hind sight of the farmers. They only presume that these trees are made into particular products; but the method of making them is unknown to the farmers.

After selling and harvesting the trees, these are transported to the industries. Sadly, Region IX has no industry to process Falcata products. These companies can be found in Region $\mathrm{X}$ in Ozamiz City. Falcata is used the paper industry. PICOP Surigao has been mentioned to have started the paper business. It also is useful in the wood industry to be made into plywood and compact board.

In their narration, "The number one use of falcata is paper" [P5: 222]; "I have no idea of the paper quality but I just know paper production in PICOP Surigao because they are the number one supplier of Falcata. Their primary aim is paper production. There is also one in wood production especially the making of compact board. Production has come to Ozamiz. The miscellaneous parts of the tree which cannot be used are made into powder form. They make them into compact boards. They are like plywood. I don't know what they mixed it with. They can make thick or thin compact boards" [P5: 225-237].

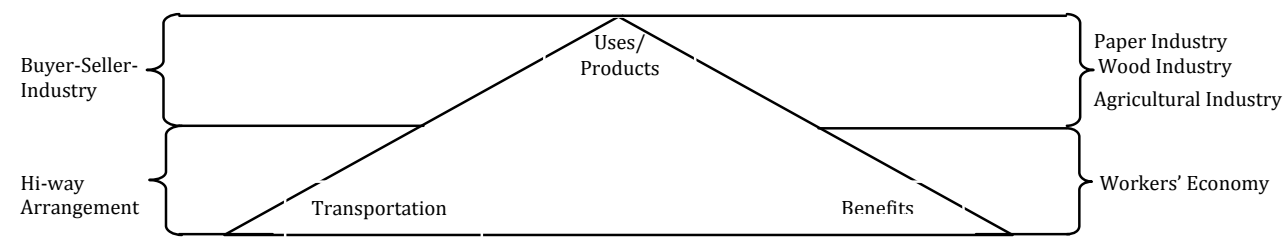

Figure6: Industrialization Key Concepts

Tree farming can give economic benefits to all the actors of the endeavor. For personal benefits, the farmers can get profit from it. Despite having troubles in 
planting, the capital are just too minimal compared to the gains. The workers who render human labor in farming also get paid for their services. This is already their income. The company of trucks and haulers can sustain their company because more planters ventured into tree farming too.

With the lucrative financial gains at stake, farmers opt to plant this type of trees with varying degrees of knowledge about the tree, different viewpoints of the tree market, and diverse perspectives of the industrialization of the trees grown [2]. The stories of assuring and distressful outlooks of tree farmers reveal much about the Falcata tree industry (p.2-3).

\section{Discussion}

Based on the results, there are some changes in the order of activities in falcata tree farming. Pre-planting, planting, marketing, harvest and industrialization are the most logically positive narration [15] of events (p. 99101), as shown in figure 7 . This is probably because planters never cut trees unless they are assured there is someone to buy; and the payment has already been made. Consistent with Freytag's pyramid, the climax is the highest point of interest. In the case of tree farming, farmer's feeling of relief is when they can select a buyer to sell their trees to. Financial gain is an element of change from their life's status quo. With the money they get from selling trees, they can pay off some credits, buy properties and augment their standard of living.

For aesthetic finality, figure 7 summarizes their stories; and to maintain the post-structuralist stance, the figure looks like this:

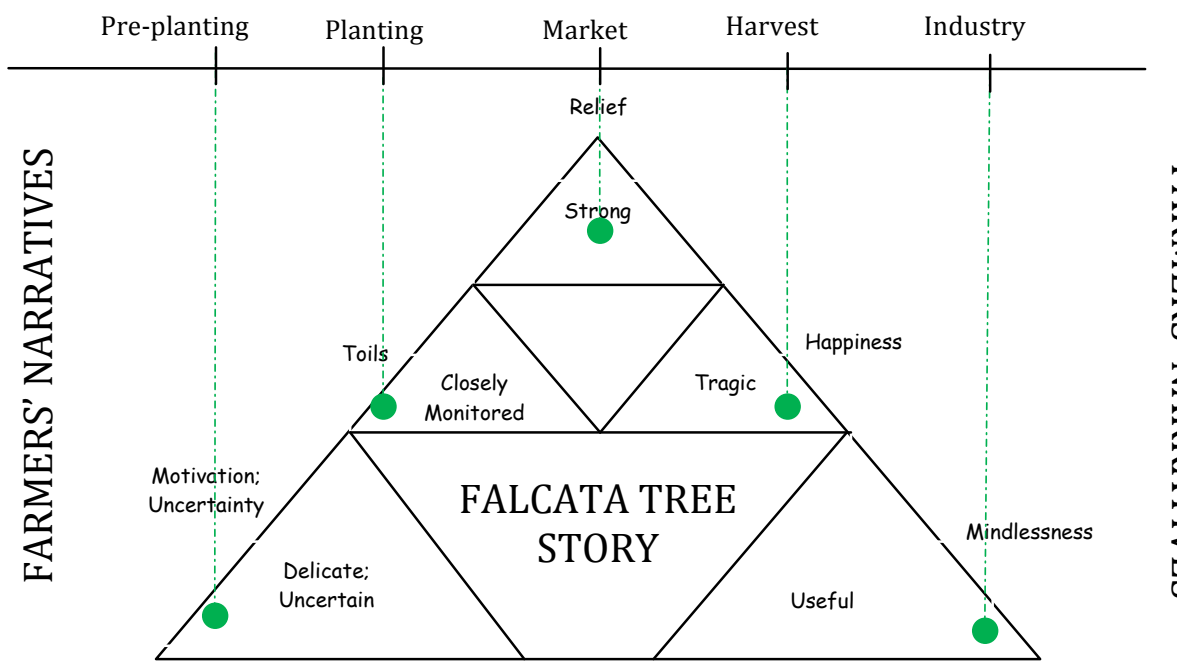

Figure 7: Revised narrative structure of Falcata Farmers

The figure resembles the simplistic development of activities. Listening to the perspectives of the farmers, there are some hidden social implications despite the fluidity of their responses. Farmers can withstand the troubles especially when the benefit is promising. For narrative fidelity, the tree story is from the little stories of farmers put up together to document the growth of the trees. However, 
by narrating these tree events, part of being farmers have surfaced. The emotions revealed outside the pyramid are interpretive farmer's perspectives.

From the beginning, the trees are uncertain to grow especially that they are delicate and the farmers are uncertain whether the silviculture being practiced is good. This includes selection of seeds [18]; and climatic conditions [19]. The participants often attribute the presence of worms and insects to climate. However, some authors [16] said that host plant identity is more important to influence the colonizing herbivore community than climate (1542-1543). Nonetheless, other authors [4] identify the issues of non-government reforestration but had been erratic. For the participants as private owners, their main motivation is to earn rather than to cover the land with trees.

The main purpose why government has been encouraging farmers to plant trees by luring them with the income is to increase forest cover [4, 20, 21]. This is done by mobilizing communities to manage tree plantation [22] (p.55), and implementing no collection [4] to alleviate global warming as trees have potency of carbon accumulation [8]. This is why all the participants have narrated the success stories of other farmers who marketed trees already. Never did it occur to them that they get losses in tree farming. However, the ecological side has been missing in their narratives. Government interventions are stipulated in the Department of Environment and Natural Resources (DENR) Memorandum Circular No. 99-20 for tree registration; DENR Memorandum Circular 97-09 for the inspection by CENRO personnel; and DENR Memorandum Circular 99-20 issuance of certificate of tree plantation ownership [23].

There are some studies which concepts have not been mentioned by the participants. A study [7] revealed that exotic trees planted on farmer's fields have similar growth rate (p. 8-9). Site characteristics should be complemented with management. In the responses, they often refer to the site as the main reason why trees grow at a dissimilar pace. Authors [23] mentioned the root oxygen deficiency; and some others [11] mentioned about the biomass changes. A group of authors [25] said that monitoring, forecasting, planning and mitigation are different disease management tactics (p.135). These are familiar to the participants. Nonetheless, one study [26] has other included experimental approaches which have never been mentioned by the participants; and that is rotational planting of trees aging from four to twelve to generate income annually; rather than plant and harvest the trees at the same time (p. 18-19).

For marketing stage, the government has set guidelines stipulated in DENR Administrative Order No. 1999-20. Although DENR Field Office presents the differing prices of falcata by region, an author [26] recommends tree farming as a more attractive option to raise productivity and income on the excess land that are not intended for annual crops. Moreover, a government agency [28] mentions the profitability of tree farming to farmers (p. 9). Yet, researchers [13] said it is on the choice of technology in marketing. Other researchers [10] believed that four to six year-old trees are more cost effective as long as they measure $16 \mathrm{~cm}$ above in diameter. The farmer-participants knew about these aspects however, they never mentioned about selling trees as early as four years old; rather than wait for eight years.

In order to harvest trees, harvesters must conform to DENR Memorandum Circular No. 99-20 and to transport timber products from registered tree plantation, harvesters need to comply with DENR Memorandum Circular No. 99- 
20. The complexities of compliance may be the reason why farmers opt to sell the trees rather than harvest these by themselves.

The farmers little realized the benefits of the products Falcata could be made into. Aside from paper as has been always mentioned by the farmers, other researchers [1] identify finger-jointed laminated panel, three-play plywood, and packing material as the finished products. Other reserachers [9] pointed out that farmers can have high income in the products by utilizing logging wastes (p. 910). A participant has mentioned that buyers buy the whole plantation. Hence, it is not to the profitability of the planters anymore, but to the buyers.

Finally, the government also sets policies and regulations in tree farming for future prospects in timber production [9]. However, there are policies that do not yield positive results. For instance, Executive Order 23 in 2011[30], or known as the moratorium of logging activities, has paralyzed the wood industry despite its goal in protecting the Philippine forests [31]. It cannot be undermined because there are only four countries in the Association of Southeast Asian Nations as the supplier of wood; which are the Philippines, Vietnam, Indonesia and Thailand [3]. In this case, someone [27] mentioned that farm grown trees have been supplying for domestic wood demand, which could be a win-win solution to the dwindling timber production. Nevertheless, the farmers are mindless about the usefulness of the falcata trees in wood production. They may mention some products, but these are reported hearsays only.

\section{Conclusion}

Falcata tree farming in Sergio Osmeňa, Zamboanga del Norte has not been maximally explored yet by most of the farmers. Shifting from common crop cultivation to tree plantation is motivated mainly by the farmers in the neighboring regions who claimed the economic benefis of Falcata tree plantation. Even with little knowledge on the characteristics of the tree, farmers rest on the assurance of return of investment and personal benefits in planting this type of tree. Farmers undermine the troubles they encounter especially from the preplanting and planting stages because they are eyeing for the economic benefits from marketing to industrialization of the trees.

\section{Acknowledgment}

Words of gratitude are accorded to Cebu Normal University-Ethics Review Committee; to Dr. Edsel Inocian and Mr. Manases Vasquez; and to the Falcata Farmers of Region IX, Philippines..

\section{References:}

[1] Krisnawati H, Varis E, Kallio M, Kanninen M. Paraserianthes falcataria (L.) Nielsen: ecology, silviculture and productivity. Bogor, Indonesia: CIFOR; 2011. 
[2] International Tropical Timber Organization [ITTO]. Genetic conservation, utilization and management of gall rust resistant strains of Falcataria Moluccana growing in the Philippines; 2014.

[3] Hidayat H. In search of sustainable Plantation Forestry, Pulp and Paper in ASEAN: Kyoto working papers on area studies. G-COE Series. 2011;112:1-185.

[4] Israel DC, Bunao DF. Value Chain Analysis of the Wood Processing Industry in the Philippines. Philippine Wood Producers Association, 2010; 8(5): 1-36.

[5] Clarke KR, Somerfield PJ, Gorley, RN. Testing of null hypotheses in exploratory community analyses: similarity profiles and biota-environment linkage. Journal of Experimental Marine Biology and Ecology. 2008; 366: 56-69. Available from: doi:10.1016/j.jembe.2008.07.009

[6] Bertomeu MG. Smallholder maize-timber agroforestry systems in Northern Mindanao, Philippines: Profitability and contribution to the timber industry sector. The International Conference on Rural Livelihoods, Forests and Biodiversity. 2003; 19-23.

[7] Martin FS, Lusiana B, Noordwijk M. Tree Growth Prediction in Relation to Simple Set of Site Quality Indicators for Six Native Tree Species in the Philippines. International Journal of Forestry Research. 2010. Available from: doi:10.1155/2010/507392

[8] Labata MM, Aranico EC, Tabaranza ACE, Patricio JHP, Amparado Jr. RF. Carbon stock assessment of three selected agroforestry systems in Bukidnon, Philippines. International Journal of the Bioflux Society. 2012; 1 (1). Available from: http://www.aes.bioflux.com.ro/docs/AES_4.1.2.pdf [Accessed 20th December 2017].

[9] Carandang, AP, Carandang MG, Camacho LD, Camacho SC, Aguilon BC, Gevaña DT. Profitability of Smallholder Private Tree Plantations in Talacogon, Agusan Del Sur, Philippines. Ecosystems \& Development Journal. 2015; 5 (3): 3-11.

[10] Alipon MA, Alcachupas PL, Bondad EO, Cortiguerra EC. Assessing the Utilization of Falcata [Falcataria moluccana (Miq.) Barneby \& J. W. Grimes] for Lumber Production. Philippine Journal of Science. 2016; 145 (3): 225-235.

[11] Sarmiento RT, Varela RP. Assessing the Biomass Potential of Major Industrial Tree Plantation Species for Green Energy Production. Open Journal of Forestry.2015; 5, 557-562. Accessed from: http://dx.doi.org/10.4236/ojf.2015.55049

[12] Jayagoda DD. A Unique Case Study of Tree Plantation Bringing Increased Forest Cover to Puerto Princesa, Philippines. Journal of Sustainable Development. 2015; 8 (1). Accessed from doi:10.5539/jsd.v8n.

[13] Laarman J, Virtanen K, Jurvelius M. Choice of technology in forestry: a Philippine: case study. Quezon City: International Labour Office New Day Publishers; 1981.

[14] Bixler RP. The political ecology of local environmental narratives: power, knowledge, and mountain caribou conservation. Journal of Political Ecology. 2013; 20: 273-285. Accessed from: https://s3.amazonaws.com/academia.edu.documents/38266170/Bixler.pdf?

AWSAccessKeyId=AKIAIWOWYYGZ2Y53UL3A\&Expires $=1513760465 \&$ Signature $=\% 2$ FQQDS EZlcYAKJ5cRybZBNgnw7fc\%3D\&response-content-disposition=inline\%3B\%20 filename\%3DThe_political_ecology_of_local_environme.pdf [Accessed 20th December 2017].

[15] Universit 'e Libre de Bruxelles (ULB), University of Bonn. The forest narratives. Accessed from hss.ulb.uni-bonn.de/2011/2679/2679-3.pdf [Accessed 20th December 2017].

[16] Andrew NR, Hughe L. Potential host colonization by insect herbivores in a warmer climate: a transplant experiment. Global Change Biology. 2007; 13:1539-1549. Accessed from doi: 10.1111/j.1365-2486.2007.01393.x

[17] Andrews, M. Ethical considerations in Narrative Research. 2016. Accessed from http://eprints.ncrm.ac.uk/2298/4/Ethical_considerations_in_Narrative_Research-1.pdf [Accessed 20th December 2017].

[18] Government of the Republic of the Philippines Forest Industry International Tropical Timber Organization (ITTO). Genetic Conservation, Utilization and Management of Gall Rust Resistant Strains of Falcataria Moluccana Growing in the Philippines (Project Proposal); 2014.

[19] Bronwyn C. Trees for Farm Forestry: 22 Promising Species Temperate/Tropical Wet/Dry Use/Potential. Rural Industries Research and Development Corporation; 2008.

[20] Ecosystems Research and Development. Initial Key Findings: Philippine Climate Change Assessment. Bureau Department of Environment and Natural Resources Canopy International. 2014; 40 (2).

[21] Department of Environment and Natural Resources (DENR-NAMRIA). Compendium of Philippine Environment Statistics. Republic of the Philippines Philippine Statistics Authority; 2014.

[22] Lasco RD, Pulhin JM. Environmental impacts of community-based forest management in the Philippines. Int. J. Environment and Sustainable Development. 2006; 5 (1), 46-56. 
[23] DENR Memorandum Circular. DENR Policies on Tree Registration, Harvesting, Transport and Marketing Tree Registration. Accessed from: http://www.bmb.gov.ph/elibrary/mainmenupolicies-52359/dmo-dmc [Accessed 20th December 2017].

[24] Pezeshki SR, DeLaune RD. Soil Oxidation-Reduction in Wetlands and Its Impact on Plant Functioning. Biology. 2012; 1: 196-221. Accessed from: doi:10.3390/biology1020196

[25] Sturrock RN, Frankel SJ, Brown AV, Hennon PE, Kliejunas JT, Lewis KJ, Worrall JJ, Woods AJ. Climate change and Forest Diseases. Plant Pathology. 2011; 60; 133-149. Accessed from: doi: $10.1111 / \mathrm{j} .1365-3059.2010 .02406 . x$

[26] Varis E. Stand growth and management scenarios for Paraserianthes falcataria smallholder plantations in Indonesia; 2011. Accessed from: https://helda.helsinki.fi/bitstream/handle/10138/27243/Eveliina_Varis.pdf?sequence=1 [Accessed 20th December 2017].

[27] Bertomeu M. Small-scale Forest Economics. Management and Policy. 2006; 5 (1): 57-82.

[28] National Economic Research and Business Assistance Center. (n. d.). Falcata Production. Accessed from: https://docs.google.com/file/d/0B0K3lOqVzxCbZDhFZVByVWNpWmc /edit [Accessed 20th December 2017].

[29] Carandang AP. Assessment of the contribution of forestry to poverty alleviation in the Philippines. Forestry Development Center, University of the Philippines Los Baños College of Forestry and Natural Resources. Accessed from: www.fao.org/3/a-i2732e/i2732e03.pdf [Accessed 17th October 2017].

[30] EXECUTIVE ORDER NO. 23 dated February 1, 2011. Accessed from: http://www.officialgazette.gov.ph/2011/02/01/executive-order-no-23-s-2011/ [Accessed 20th December 2017].

[31] Paqueo VB, Israel DC. Planting seeds of self-defeat: Effects of unrealistic regulations on the Caraga wood industry and forest conservation. DISCUSSION PAPER SERIES NO. 2016-51; 2016.

http://www.tageo.com/index-e-rp-v-65-d-m3377823.htm 